\title{
Indigenous Rights in the Making: The United Nations Declaration on the Rights of Indigenous Peoples
}

\author{
Jérémie Gilbert*
}

\section{Introduction}

In the last decades, there has been a growing focus on the rights of indigenous peoples under the UN machinery. The UN declared the decade 1994-2004 as the first 'World Decade on the Rights of Indigenous Peoples' and 2005-2015 as the second decade. ${ }^{1}$ From 1994 to 2004 the theme for the first decade was 'Indigenous People: Partnership in Action'. ${ }^{2}$ The main objective was the strengthening of international cooperation for the solution of problems faced by indigenous people in such areas as human rights, the environment, education and health. As a result, in 2002, the Permanent Forum on Indigenous Issues was established as an advisory body to the UN Economic and Social Council. ${ }^{3}$ Yet, one of the central purposes of the decade was the development, standard setting and mainstreaming of the human rights of indigenous peoples. One of the crucial issues was the adoption of a universal declaration on the rights of indigenous peoples. The adoption of a universal declaration on the rights of indigenous peoples is seen by many indigenous peoples as a necessary step under international law to affirm their right to a specific identity and to ensure their survival. Hence, the 'UN Declaration on the Rights of Indigenous Peoples' adopted by the Human Rights Council ${ }^{4}$ at its first session in

* Lecturer, Transitional Justice Institute, University of Ulster (Northern Ireland). The author wishes to thank Dr. Gaetano Pentassuglia and Dr. David Keane for comments on an earlier draft of this article.

1) See General Assembly resolution A/RES/48/163 (1994) and resolution A/RES/59/174 (2005).

2) General Assembly resolution 48/163 of 21 December 1993.

3) Economic and Social Council resolution 2000/22.

4) Difference has to be made between the 'UN Draft Declaration', which was adopted in 1994 by the Sub-Commission, and the 'UN Declaration', which was adopted by the Human Rights Council in June 2006. See UN Declaration on the Rights of Indigenous Peoples, Human Rights Council resolution 2006/2 (29 June 2006), contained in UN Doc. A/HRC/1/L.10 (Annex). At the time of writing, the text is to be adopted by the UN General Assembly. 
June 2006 has to be seen as a significant development in the role of the UN for the protection of indigenous peoples' rights. One of the key mottos of the UN has been to support partnership between States and indigenous peoples. As affirmed in the preamble, the Declaration should serve as "a standard of achievement to be pursued in a spirit of partnership and mutual respect." This aspect of the Declaration is crucial and reflects the role that UN human rights machinery has been playing over the last decades, which after centuries of oppression and cultural assimilation has supported the establishment of a dialogue between States and indigenous peoples.

The present article explores the potential significance of the adoption of an international declaration in the development of international legal standards on the rights of indigenous peoples. A continuing discussion regarding indigenous peoples' rights under international law is to appreciate to what extent indigenous peoples could find support under existing international legal standards (notably non-discrimination and equality), or whether, based on the specificity of their claims, there is a need to establish new ad hoc standards. Hence, in terms of the debates surrounding the development of indigenous peoples' rights, one of the main contentions is focussed around the question of whether a specific regime is necessary or whether they can be subsumed under general human rights law. Despite the recent expanding jurisprudence generated by the UN treaty monitoring bodies on indigenous peoples' rights, ${ }^{5}$ there are still questions on whether general international human rights law can successfully accommodate indigenous peoples' specific claims. Within such framework, the present article wishes to examine to what extent the adoption of an international declaration could serve as a positive force in the development of the rights of indigenous peoples under international law. While the article generally focuses on the Declaration, this is done with the view of examining the general development of specific rights for indigenous peoples. By examining in depth the debates surrounding the Declaration, the article wishes to explore how international law has developed on several issues that make indigenous peoples' rights a very specific branch of international law. Furthermore, the article will focus on the issues that have been especially contentious in the drafting of the Declaration, namely the recognition of indigenous peoples as 'peoples' under international law and the affirmation of their collective land rights. These two issues have been at the centre of the discussion in the establishment of the Declaration, and debate on these two core issues reflects the importance of developing rights for indigenous peoples under international law. Before analysing these two core issues, the article will first explore the long road that led to the adoption of the Declaration by the Human Rights Council in June 2006. 


\section{One Step Forward, Two Steps Backwards: The Difficult Birth of the UN Declaration on the Rights of Indigenous Peoples}

As highlighted earlier in the introduction, there has been a long debate amongst international lawyers and international institutions on the need to develop a specific branch of international law to protect indigenous peoples' rights or whether indigenous peoples should find protection under the universal international regime that is applicable to all human beings. The following analysis explores, first, the debate on the need for a specific branch of international law in addressing indigenous peoples' specific claims and, second, how this debate had repercussions on the negotiations on the eventual adoption of a universal declaration.

\subsection{Towards Specific Indigenous Rights}

When addressing the rights of indigenous peoples under international law, the first reference is the International Labour Organisation (ILO). The two ILO Conventions (ILO Convention 107 (1957) and ILO Convention 169 (1989)) remain the only international binding instruments that specifically provide a detailed list of rights for indigenous peoples. However, the ILO Convention 107 has been rightly criticised for being assimilationist, ${ }^{6}$ and the ILO Convention 169 has so far received 17 ratifications. $^{7}$ Thus, we are far from a strong international legal framework on the rights of indigenous peoples. Yet, this is only one way of looking at international law and indigenous peoples as there is a very large jurisprudence on the rights of indigenous peoples emerging from other international bodies using general international instruments in their approach to indigenous peoples' rights. This two-way vision depends on whether one would examine indigenous peoples' rights through the lens of special rights for indigenous peoples or whether one believes that indigenous peoples' rights are part of the larger category of human rights law.

This is reflected in the debate on the need for a specific category of rights for indigenous peoples or whether indigenous peoples' claims could find protection under the general human rights discourse on non-discrimination. Cornastell and Primeau suggest that the existing body of human rights law is adequate to address indigenous peoples' claims. ${ }^{8}$ From this perspective, focusing on the development

6) Convention Concerning the Protection and Integration of Indigenous and Other Tribal and Semi-Tribal Populations in Independent Countries (ILO Convention 107), 328 UNTS 247 (1957).

7) Convention Concerning Indigenous and Tribal Peoples in Independent Countries (ILO Convention 169), reprinted in ILM 1382 (1989).

8) J. Corntassel and T. H. Primeau, 'Indigenous 'Sovereignty' and International Law: Revised Strategies for Pursuing 'Self-Determination', 17 H.R.Q. (1995) p. 342. 
of specific instruments would be counterproductive. As Brownlie puts it: "[T]he heavy reliance on the still relatively controversial category of "indigenous peoples" is difficult to understand and, frankly, it smacks of nominalism and a sort of snobbery." On the other side of the spectrum, Berman has argued that indigenous peoples' rights constitute a sui generis category of rights that arise outside of the positive law system. They are "pre-existing rights in the sense that they are not developed from the legal system of surrounding states but [they] arise sui generis from the historical condition of indigenous peoples as distinctive societies with the aspiration to survive as such." ${ }^{10}$ Kingsbury has pointed out that indigenous peoples' claims under international law come from five main different directions: non-discrimination, minority rights, self-determination, historical sovereignty and sui generis claims. ${ }^{11}$ Hence, while indigenous rights might find some ground within the main human rights discourse, Kingsbury points out that there are still some aspects of indigenous claims that require a sui generis category.

Recent legal decisions affecting indigenous peoples support the development of a specific indigenous approach to legal standards. For example, the 2001 decision of the Inter-American Court of Human Rights (IACHR) in the Awas Tingni case, which is often regarded as one of the landmark decisions regarding indigenous peoples' rights in recent years, ${ }^{12}$ significantly supports the development of a specific approach to indigenous peoples' rights. What has been remarkable in this landmark decision from the IACHR is that the judges opted for the 'indigenisation' of general human rights norms. While Article 21 of the American Convention on Human Rights regarding property rights is framed in a general way, the judges pointed out that such rights do have a specific meaning for indigenous peoples. As the Court stated: "[T]hrough an evolutionary interpretation of international instruments for the protection of human rights (. . .) it is the opinion of this Court that article 21 of the Convention protects the right to property in a sense which includes, among others, the rights of members of the indigenous communities within the framework of communal property (. ..)."13 One of the main limitations regarding the adaptability of the general human rights discourse to indigenous peoples' specific claims is its individualistic

9) I. Brownlie, Treaties and Indigenous Peoples (Oxford University Press, 1992) p. 63.

10) H. Berman, 'Are Indigenous Populations Entitled to International Juridical Personality?', 79 ASIL Proc. (1989) p. 193.

11) B. Kingsbury, 'Reconciling Five Competing Conceptual Structures of Indigenous Peoples' Claims in International and Comparative Law', in P. Alston (ed.), Peoples' Rights (Oxford University Press, 2001) p. 109.

12) J. Anaya and C. Grossman, 'The Case of Awas Tingni v. Nicaragua: A New Step in the International Law of Indigenous Peoples', 19:1 Ariz. J. Int'l \& Comp. Law (2002).

13) The Mayagna (Sumo) Awas Tingni Community v. Nicaragua, Judgment of 31 August 2001, IACHR, (Ser. C) No. 79 (2001), para. 148. 
framework. On this point, the decision of the Inter-American Court highlights that general human rights could be adaptable to the specificity of indigenous peoples' claims. However, in the same breath, the judges pointed out that the decision relied on the Court's 'evolutionary' approach to international human rights law, relying primarily on the ILO Convention 169, the UN Declaration and the Organization of American States (OAS) Proposed American Declaration as well as specific national laws on indigenous peoples' rights. Thus, the 'indigenisation' of the general right to property was based on more specific instruments on the rights of indigenous peoples. From this perspective, the InterAmerican Court's progressive approach seems to indicate that the most positive development regarding the content of human rights discourse in relation to indigenous peoples comes from the ILO Convention 169 and the UN and OAS Declarations. From the judges' point of view, there is an emerging corpus of international law on the rights of indigenous peoples and the 'indigenisation' of Article 21 of the American Convention was a reflection of this development. This indicates that even though general human rights norms can be used to protect the rights of indigenous peoples, this is complemented by the emergence of a specific legal framework that encompasses more distinctively indigenous peoples' claims.

On a theoretical level, with reference to the debate on 'general human rights versus specific indigenous regime', the choice might not be of one versus another. Rather, an adequate level of protection for indigenous peoples might be based on both paths. On the one hand, general human rights norms on non-discrimination and equality are flexible enough to include some protection for indigenous peoples, but on the other hand, such flexibility relies on a parallel development of a specific regime of protection. The opening on property rights that took place at the Inter-American level was based on the fact that "human rights treaties are live instruments whose interpretation must adapt to the evolution of the times and, specifically, to current living conditions", and on the indication that this evolution of the times was reflected in the development of a specific regime of protection for indigenous peoples. Hence, the development of jurisprudence from the UN human rights treaty bodies such as the Human Rights Committee (HRC), the Committee on Economic, Social and Cultural Rights (CESCR) or the Committee on the Elimination of Racial Discrimination (CERD) on the rights of indigenous peoples does not preclude the development of a specific regime. Quite the opposite; these developments indicate that 'the evolution of the times' supports the emergence of a specific focus on the protection of indigenous peoples. In the context of such developments, a general declaration has to be seen as a statement of minimum standards on the rights of indigenous peoples. This approach has been put forward by many indigenous representatives who point out that the establishment of a universal declaration on the rights of 
indigenous peoples should be seen to be part of the "progressive development" of international law. ${ }^{14}$

Furthermore, one of the dangers in the development of international law regarding indigenous peoples' rights is increasingly the problem of coherence. The rights of indigenous peoples gradually developed under very different international institutional settings, including the work of the ILO, the World Bank, the Conference of the Parties to the Convention on Biological Diversity, the United Nations Forum on Forests, UN Development Programme (UNDP), UN Conference on Environment and Development (UNCED), World Intellectual Property Organization (WIPO) and the different UN human rights monitoring bodies. However, there is no coherent affirmation of indigenous peoples' rights under international law. Notably, crucial issues such as land rights, collective rights and self-determination need to be addressed in a formal and particular way to ensure the coherence of international law on indigenous peoples' rights. The development of a universal declaration could be seen as one attempt to address in a systematic manner the different rights that are specific to indigenous peoples.

\subsection{The Long Battle of the Working Groups}

To get to the Human Rights Council in June 2006, the text of the UN Declaration had to climb all the ladders of the UN hierarchy. Everything started at the Sub-Commission on the Protection and Promotion of Human Rights (hereinafter 'Sub-Commission') level. The UN Working Group on Indigenous Populations (WGIP) was established in 1982 as a subsidiary organ of the SubCommission with a two-fold mandate:

- to review developments pertaining to the promotion and protection of human rights and fundamental freedoms of indigenous peoples;

- to give attention to the evolution of international standards concerning indigenous rights. ${ }^{15}$

When the WGIP started its work, the only international instrument relating to the rights of indigenous peoples was the ILO Convention 107. It had a limited number of States parties and was seen as a very assimilationist text by most indigenous peoples. Against this background, the WGIP started to work on the

14) See the joint statement issued by several indigenous organisations, Urgent Need to Improve the U.N. Standard-Setting Process Importance of Criteria of 'Consistent with International Law and Its Progressive Development, UN Doc. E/CN.4/2005/WG.15/CRP.3 (24 November 2005).

15) Economic and Social Council resolution 1982/34. 
text of a declaration on the rights of indigenous peoples. The WGIP was actually the first global forum for indigenous peoples at the UN, and indigenous representatives attending the meetings pointed out the lack of international standards. Based on the specific nature of the WGIP, which remains an open forum for indigenous peoples, the Working Group started to draft a text taking into account the comments and suggestions of indigenous peoples' representatives. At its 11th session, in July 1993, the Working Group agreed on a final text for the 'Draft UN Declaration on the Rights of Indigenous Peoples' and submitted it to the Sub-Commission. ${ }^{16}$ The text was then adopted by the Sub-Commission in $1994 .{ }^{17}$

The text of the Draft Declaration was sent to the Commission on Human Rights for its adoption. The Commission established an inter-sessional working group, the Working Group on the Draft Declaration (WGDD), to review the text. ${ }^{18}$ The WGDD was composed of representatives of member states of the Commission on Human Rights. Over the years, the WGDD has been meeting several times both formally and informally, amid resolutions from the Commission on Human Rights and the General Assembly calling for the adoption of the Draft Declaration. Moreover, one of the outcomes of the first UN decade on the rights of indigenous peoples (1994-2004) was expected to be the adoption of a declaration on the rights of indigenous peoples by the General Assembly. Despite such calls, participants to the debates of the WGDD could not agree on several points. Accordingly, 12 years after its adoption by the SubCommission, the text was still far from being ready for adoption as only two out of the 45 Articles of the Draft Declaration had been adopted. ${ }^{19}$

There have been different phases in the life of the WGDD, yet the main stumbling blocks were on the issues of self-determination, collective rights and land rights. To help the negotiations, the WGDD divided its work between different clusters exploring possible agreements on these different issues. ${ }^{20}$ After a few meetings of the WGDD, it became clear that some States were taking different approaches regarding the text proposed by the Sub-Commission. In the first group were a limited number of States willing to support the text of the Draft Declaration as adopted by the Sub-Commission (or with very minor

16) Resolution 1995/32, the text of the Draft Declaration on the rights of indigenous peoples is contained in the 1994 Sub-Commision Annual Report, UN Doc. E/CN.4/Sub.2/1994/56.

17) Resolution 1994/45.

18) Economic and Social Council resolution $1995 / 32$.

19) These two Articles (Article 5 on the right to nationality and Article 43 on gender equality) were endorsed at the second session of the WGDD.

20) Cluster on self-determination and autonomy (Articles 3, 31 and 36); cluster on land rights (Articles 25, 26, 27, 28, 29 and 30); cluster on ethnocide, distinct identity and armed conflicts (Articles 7, 8 and 11). See UN Doc. E/CN.4/2003/92. 
amendments). ${ }^{21}$ In the second group were the States supporting in principle the adoption of a declaration while opposing the Draft Declaration adopted by the Sub-Commission, notably on the issue of self-determination and land rights. Finally, in the third group were the States more generally opposed to the recognition of the specificity of indigenous peoples' claims and rejecting core issues such as the existence of collective rights. From an indigenous peoples' perspective, the debates remained very opaque as indigenous representatives were not formally part of the process. Whereas at the Sub-Commission stage the WGIP acted as an open forum with some space for indigenous peoples to take active part in the development of a future declaration, at the WGDD the process mainly remained behind close doors with no formal space left to indigenous peoples' representatives.

However, indigenous organisations and indigenous representatives coming from the four corners of the globe did manage to maintain a very successful lobbying group, notably through the establishment of the Indigenous Peoples Caucus. To react to some of the States' unwillingness to see the emergence of a declaration, indigenous representatives began a debate on whether a 'no changes' position should be adopted regarding the text of the Sub-Commission. ${ }^{22}$ Finally, indigenous representatives agreed to consider changes to the text to the extent that such changes comply with the principles of international law enshrined in the UN Charter and notably the principles of equality and non-discrimination. Overall, the debates at the WGDD level were seen by most indigenous peoples as a very important battle for the future of indigenous rights. As several indigenous organisations pointed out in 2005: "[I]t has become increasingly clear that there is an urgent need to improve the current U.N. standard-setting process on the rights of Indigenous peoples." 23

Ultimately, at the 11th meeting of the WGDD in February 2006, the Chairperson-Rapporteur of the Working Group, Mr. Chavez, tried to break the deadlock by proposing that a revised version of the text incorporating several amendments would be presented to the Commission on Human Rights (now Human Rights Council) for adoption. ${ }^{24}$ In June 2006, when the newly established Human Rights Council held its first meeting, the UN Secretary General in his opening address to the Council called for the adoption of the Draft

21) Such States usually included members of the Group of Latin America and Caribbean Countries (GRULAC) such as Chile and Mexico. See UN Doc. E/CN.4/2002/WG.15/CPR.6 and UN Doc. E/CN.4/2003/92.

22) Indigenous representatives agreed on a set of criteria for reviewing the text; the changes should be "reasonable, necessary and improve or strengthen the text." UN Doc. E/CN.4/1999/WG.15/CRP.2.

23) Supra note 14.

24) UN Doc. E/CN.4/2006/79. 
Declaration "at the earliest opportunity." Taking the lead, Peru presented a resolution sponsored by several States calling for the adoption of the text as proposed in the report of the WGDD. ${ }^{25}$ The representative of Canada called for a recorded vote on the draft resolution, which was adopted by 30 votes to two (with 12 abstentions). ${ }^{26}$ Hence, after more than 20 years of negotiations, the Human Rights Council adopted the 'UN Declaration on the Rights of Indigenous Peoples' and recommended it for adoption by the UN General Assembly.

While this clearly indicates a move towards a specific protection of the rights of indigenous peoples, the recourse to a vote rather than an adoption by consensus suggests that certain issues were still outstanding for a few States. As the recording of the votes indicates, States do not have issues with the general human rights that the Declaration reaffirms; the main concerns that were raised relate to the issues of definition, self-determination, land rights and collective rights. ${ }^{27}$ For example, the representative of the United Kingdom observed that "it did not accept the concept of collective rights in international law", and the representative of India pointed out that the fact that the text did not contain a definition of 'indigenous' and 'self-determination' was problematic. These declarations illustrate some of the important points that need to be analysed to understand the importance of the Declaration adopted by the Human Rights Council and why in November 2006 the Third Committee of the General Assembly deferred the adoption of the text. ${ }^{28}$

\section{Indigenous Peoples as 'Peoples': Definition, Self-determination and Political Participation}

Regarding indigenous peoples' rights under international law, there is a perpetual contention on whether or not indigenous peoples fall into the sphere of peoples' rights. As it is a clear tenet of international law that 'peoples' have the right to

25) UN Doc. A/HRC/1/L.3. Resolution presented by Peru and supported by Armenia, Benin, Congo, Costa Rica, Cuba, Cyprus, Denmark, Estonia, Finland, France, Greece, Guatemala, Haiti, Lesotho, Mexico, Nicaragua, Norway, Panama, Portugal, Slovenia, Spain, and Venezuela, Andorra, Austria, Bolivia, Cameroon, Croatia, Ecuador, Ethiopia, Former Yugoslav Republic of Macedonia, Honduras, Hungary, Italy, Latvia, Libyan Arab Republic, Liechtenstein, Lithuania, Luxembourg, Malta, Saint Kitts and Nevis, South Africa, Sweden and Switzerland.

26) For details, see UN Doc. A/HRC/1/L.10 (30 June 2006), and see comments on the voting in the discussion below.

27) For illustrations, see the comments from Argentina, the United States of America, the United Kingdom and Ukraine.

28) The draft resolution proposed by the Third Committee calls "to defer consideration and action on the United Nations Declaration on the Rights of Indigenous Peoples to allow time for further consultations thereon." See UN Doc. A/C.3/61/L.57/Rev.1 (28 November 2006). 
self-determination, the rights of indigenous peoples have grown in the shadow of this concept. To some extent, the reference to peoples' right to self-determination has been the most contentious issue in the development of the UN Declaration. More generally, the reference to 'peoples' also raises the issue of definition as under international law the question of who are 'peoples' entitled to self-determination has not been resolved. Hence, the following discussion examines to what extent the UN Declaration casts some light on the debates relating to definition and selfdetermination.

\subsection{Definition: Who are the Indigenous Peoples?}

Whereas other international instruments such as the ILO Convention 169 and the World Bank Operational Directives ${ }^{29}$ include a definition on who indigenous peoples are, the proposed text of the UN Declaration does not contain such a specific definition. The need to have a definition in the Declaration has been a contentious issue throughout the drafting of the text. On the one hand, several States supported the inclusion of a definition, affirming that defining 'indigenous peoples' was crucial in the context of the Declaration while, on the other hand, some of the States' representatives pointed out that "applying the concept universally would lead to dilution of the issue, thus harming the true beneficiaries of the rights enshrined in the declaration." ${ }^{30}$ It was highlighted that defining 'indigenous peoples' could lead to the creation of an inflexible and exclusive concept that might not be relevant in certain regions of the globe. ${ }^{31}$ Henceforth, the text adopted by the Human Rights Council does not provide a definition, and the openness of the document in this regard engages the concept of self-identification. The choice of self-identification was formerly clearly expressed in the text of the Draft Declaration, as Article 8 relating to identity stated:

Indigenous peoples have the collective and individual right to maintain and develop their distinct identities and characteristics, including the right to identify themselves as indigenous and the right be recognised as such. ${ }^{32}$

29) World Bank OP and BP 4.10 on Indigenous Peoples, which in Article 4(b) refers to indigenous peoples as groups having "collective attachment to geographically distinct habitats or ancestral territories in the project area and to the natural resources in these habitats and territories." OP 4.10 replaces the previous OD 4.20 on Indigenous Peoples (1991) and applies to all projects for which a Project Concept Review takes place on or after 1 July 2005. See also World Bank OD 4.20 (1991).

30) See Report on the first session of the WGDD, UN Doc. E/CN.4/1996/84, p. 7.

31) On this issue, see notably B. Kingsbury, "Indigenous Peoples' in International Law: A Constructivist Approach to the Asian Controversy', 92 A.J.I.L. 414 (1998).

32) Resolution 1995/32, the text of the Draft Declaration on the Rights of Indigenous Peoples is contained in the 1994 Sub-Commission Annual Report, UN Doc. E/CN.4/Sub.2/1994/56, see Article 8. 
However, at the WGDD this article attracted some controversy as some States used it to reintroduce the idea of having a definition within the Declaration. ${ }^{33}$ As a result, at the last session of the WGDD, Mr. Chavez proposed the deletion of the Article, which does not appear in the text of the Declaration adopted by the Human Rights Council. Nevertheless, Article 9 of the Declaration maintains that: "Indigenous peoples and individuals have the right to belong to an indigenous community or nation, in accordance with the traditions and customs of the community or nation concerned." Furthermore, Article 33 affirms: "Indigenous peoples have the right to determine their own identity or membership in accordance with their customs and traditions." Hence, even though the right to identify themselves does not formally appear in the text of the Declaration, the spirit of the Declaration remains based on a self-identification perspective with a right for indigenous individuals to belong to an indigenous community.

During the drafting stages, some States expressed their concerns with selfidentification as this could leave access to the rights in the Declaration open to anyone who identified themselves as indigenous. In the future this could lead to serious legal controversies on who is entitled or not to such rights for it could authorise non-indigenous groups or individuals to claim indigenous status. However, as indigenous representatives pointed out during the negotiations, the right to self-identification requires that any individual claiming the indigenous status would have to be recognised by the members of his or her community. ${ }^{34}$ The right to self-identification is not only an individual right but also a right to be exercised and controlled by the community. Within such framework the right to self-identification is not only subjective as it is also based on an objective link between the individual(s) and the community.

The non-inclusion of a definition in the Declaration has to be seen to be part of the "growing respect for the principle of self-identification as an essential aspect of individual and group freedom (. . .)."35 Even the detailed definition contained in ILO Convention 169 refers to the centrality of self-identification as Article 1(2) states that "self-identification as indigenous or tribal shall be regarded as a fundamental criterion for determining the groups to which the provisions of this Convention apply." Likewise, the definition used by the World Bank in its Operative Directives also highlights the importance of self-identification. More generally, CERD has also referred to a right to self-identification. In its General Recommendation 8: Identification with a Particular Racial or Ethnic Group, CERD affirmed that "having considered reports from States parties

33) See the proposal from the US delegation to introduce a strict definition, text available in the annex of UN Doc. E/CN.4/2006/79, p. 23.

34) See UN Doc. E/CN.4/2003/92, p. 14.

35) Thornberry, supra note 5, p. 15. 
concerning information about the ways in which individuals are identified as being members of a particular racial or ethnic group, [the Committee] is of the opinion that such identification shall, if no justification exists to the contrary, be based upon self-identification by the individual concerned." 36 Hence, the proposed UN Declaration is part of the general development of a legal approach based on a right to self-identification.

This evolution towards a prominence of a right to self-identification has to be seen as part of the evolution of a right to self-determination for indigenous peoples. From this perspective the right to self-identification provides the freedom to identify themselves, the act of self-determining their own identity. As a leader of the Cree Nation stated: "[E]fforts to define who or what are indigenous peoples are seen as further attempts to dispossess and take away our inherent right to be. Indeed to assume a right to define indigenous peoples is to further deny our right to self-determination." ${ }^{37}$ As this quotation illustrates, the issue of definition is important in the UN Declaration as legally it recognises indigenous peoples as 'peoples' under international law, hence entitled to self-determination. The shadow of self-determination has always been a crucial issue behind the protracted discussion on definition.

\subsection{Self-Determination}

Regarding the development of the rights of indigenous peoples under international law, self-determination is certainly the thorniest issue. The affirmation of indigenous peoples' right to self-determination in Article 3 of the UN Draft Declaration was an obstacle to the adoption of the text at the WGGD level. ${ }^{38}$ Several States expressed serious reservation to the recognition of a right to selfdetermination. By contrast, indigenous representatives affirmed: "[T]he right of self-determination is the heart and soul of the declaration. We will not consent to any language which limits or curtails the right of self-determination." ${ }^{39}$ Finally, after lengthy debate, Article 3 of the Declaration adopted by the Human Rights Council recognises that indigenous peoples have the right to self-determination.

36) General Recommendation 8: Identification with a Particular Racial or Ethnic Group (Articles 1(1) and (1)(4)), contained in UN Doc. A/45/18.

37) Quoted in I. Sjorslev, 'Indigenous Peoples and the United Nations', in The Indigenous World 1995-1996 (IWGIA, Copenhagen, 1996) p. 273.

38) See discussion on Article 3, UN Doc. E/CN.4/2004/81; for an analysis of the discussion on the issue, see K. Knop, Diversity and Self-determination in International Law (Cambridge University Press, 2002) especially ch. 5.

39) As quoted in S. Pritchard (ed.), Indigenous Peoples, The United Nations, and Human Rights (Zed Books, London, 1998) p. 46. 
It reads: "Indigenous peoples have the right of self determination. By virtue of that right they freely determine their political status and freely pursue their economic, social and cultural development." Article 4 also relates to self-determination, and affirms: "Indigenous peoples, in exercising their right to self-determination, have the right to autonomy or self-government in matters relating to their internal and local affairs, as well as ways and means for financing their autonomous functions." 40

However, despite being clearly affirmed in the Declaration, self-determination remains a serious point of contention. In their joint statement at the Human Rights Council, Australia, New Zealand and the US expressed their concerns with regard to self-determination, affirming that "the provisions articulating selfdetermination for indigenous peoples in this text inappropriately reproduce common Article 1 of the Covenants." In the view of those States, this "could be misrepresented as conferring a unilateral right to self-determination and possible secession upon a specific subset of the national populace, thus threatening the political unity, territorial integrity and the stability of existing UN member states." ${ }^{11}$ This concern regarding the protection of States' territorial integrity has been one of the main issues for the States involved in the drafting of the Declaration and discussion on this issue, and it was raised at every single meeting of the WGDD. ${ }^{42}$

The text of the Declaration establishes a balance between the need to recognise the fundamental right to self-determination for indigenous peoples while addressing States' concerns on territorial integrity. Whilst the Declaration affirms indigenous peoples' right to self-determination, Article 46 of the Declaration also clearly affirms that all the rights expressed in the Declaration should be exercised in conformity with the rights recognised in the Charter of the United Nations. This framework for the application of the Declaration is significant as one of the essential principles of the UN Charter is respect for States' territorial integrity. Likewise, the Declaration also states that: "In the exercise of the rights enunciated in the present Declaration, human rights and fundamental freedoms of all shall be respected. The exercise of the rights set forth in this Declaration shall be subject only to such limitations as are determined by law, in accordance with international human rights obligations." ${ }^{33}$ Thus, the right to self-determination

40) The text was also included in the text of the Draft Declaration in its Article 31.

41) Joint statement by Australia, New Zealand and the United States of America on the Chair's Text on the Declaration on the Rights of Indigenous Peoples (Human Rights Council, 27 June 2006).

42) One of the amendments proposed to the right to self-determination as contained in the Draft Declaration included reference to the principle of territorial integrity. See proposal by Norway, UN Doc. E/CN.4/2003/92.

43) Article 46(2) of the UN Declaration. 
will apply within the existing international human rights framework on selfdetermination for indigenous peoples.

For example, when applying the right to self-determination, the jurisprudence of the HRC on Article 1 of the ICCPR would undoubtedly have to be taken into consideration. Under the reporting mechanism, the HRC has invited States to report on the implementation of Article 1 of the ICCPR regarding the right of indigenous peoples. ${ }^{44}$ The HRC has also developed a jurisprudence regarding indigenous peoples' right to self-determination under its individual complaint mechanisms. ${ }^{45}$ Hence, some of the States' arguments that the affirmation of indigenous peoples' rights to self-determination is contrary to current international standards ignores the international legal framework that has been recently developed around the right to self-determination for indigenous peoples. ${ }^{46}$

The text of the Declaration confirms this evolution towards a specific form of self-determination for indigenous peoples. During the debates at the WGDD, indigenous representatives invited States to broaden their understanding of selfdetermination by pointing out that for indigenous peoples self-determination is not only about statehood and secession. On several occasions, they have highlighted that self-determination is about free control, choice and way of life, and not only about secession. ${ }^{47}$ Opposition to the affirmation of indigenous peoples' right to self-determination also ignores the framework put in place within the Declaration. The whole text of the Declaration is about strengthening partnership between States and indigenous peoples, not about breaking away. The Declaration should be seen as a framework to organise peaceful relations between States and indigenous peoples. As Franck highlights: "[S]elf-determination postulates the right of a people in an established territory to determine its collective political destiny in a democratic fashion and is therefore at the core of the democratic entitlement." ${ }^{8}$

44) For examples, see Concluding Observations: Norway, UN Doc. CCPR/C/79/Add.112 (1999); Concluding Observations: Mexico, UN Doc. CCPR/C/79/Add.109 (1999); Concluding Observations: Australia, UN Doc. CCPR/CO/69/AUS (2000); Concluding Observation: Sweden, UN Doc. CCPR/ CO/74/SWE (2002); Concluding Observations: Canada, UN Doc. CCPR/C/CAN/CO/5, paras. 8, 9.

45) For references, see M. Scheinin, 'The Right to Enjoy a Distinct Culture: Indigenous and Competing Uses of Land', in T. S. Orlin et al. (eds.), The Jurisprudence of Human Rights: A Comparative Interpretive Approach (Åbo Akademi University Institute for Human Rights, 2000) pp. 159-222; J. Castellino and J. Gilbert, 'Self Determination, Indigenous Peoples and Minorities', 3 Macquarie Law Journal (2003) pp. 155-178.

46) See generally P. Aikio and M. Scheinin (eds.), Operationalizing the Right of Indigenous Peoples to Self-determination (Åbo Akademi University Institute for Human Rights, 2001).

47) For an illustration, see UN Doc. E/CN.4/1996/84.

48) T. Franck, "The Emerging Right to Democratic Governance”, 86 A.J.I.L. (1992) p. 52. 


\subsection{The Democratic Project: From Political Participation to Free and Informed}

\section{Consent}

The text of the UN Declaration is based upon principles of consultation and cooperation between States and indigenous peoples. There is a real democratic project behind the Declaration. This democratic project is based on a double axiom: firstly, to ensure a right for indigenous peoples to participate in the life of the State without facing discrimination and, secondly, to promote a right for indigenous peoples to engage in self-development. For example, Article 5 states: "Indigenous peoples have the right to maintain and strengthen their distinct political, legal, economic, social and cultural institutions, while retaining their rights to participate fully, if they so choose, in the political, economic, social and cultural life of the State." Hence, the democratic project behind the Declaration relies on the double affirmation that indigenous peoples should:

1. have a right to enjoy their own institutions (self-development);

2. have a say in decisions affecting them (political participation).

First, the right to enjoy their own institutions is reflected in several key articles of the Declaration that affirm that indigenous peoples have a right to maintain and strengthen their distinct political, legal, economic, social and cultural institutions and practice and revitalise their cultural traditions and customs. ${ }^{49}$ For example, the Declaration invites States to consult indigenous peoples' own institutions in issues relating to education, health, housing and other economic and social programmes affecting them. ${ }^{50}$ Furthermore, Article 34 states: "Indigenous peoples have the right to promote, develop and maintain their institutional structures and their distinctive customs, spirituality, traditions, procedures, practices and, in the cases where they exist, juridical systems or customs, in accordance with international human rights standards." This affirmation reflects the evolution of a human rights discourse that promotes cultural diversity and the right for indigenous peoples to practice their own customary systems of laws.

The second aspect of the democratic project entrenched in the Declaration relates to the right for indigenous peoples to have a say in decisions affecting them. The Declaration affirms that indigenous peoples have the right to fully participate in the institutions and processes of governance affecting their social, economic, political, cultural and educational development. For example, Article 18 reads:

Indigenous peoples have the right to participate in decision-making in matters which would affect their rights, through representatives chosen by themselves in accordance 
with their own procedures, as well as to maintain and develop their own indigenous decision-making institutions.

Article 19 goes further by affirming:

States shall consult and cooperate in good faith with the indigenous peoples concerned through their own representative institutions in order to obtain their free, prior and informed consent before adopting and implementing legislative or administrative measures that may affect them.

Hence, the proposed text of the Declaration makes a distinction between a right to participate in decisions that would affect indigenous peoples' rights and a right to consent before States implement "legislative or administrative measures that may affect them."

This distinction in the Declaration's text between a right to participate and a right to consent reflects previous debates that took place within CERD. CERD has also made reference to indigenous peoples' right to consent to decisions directly affecting them. In its General Recommendation 23 on indigenous peoples, CERD urged States to make sure "that no decisions directly relating to [indigenous] rights and interests are taken without their informed consent." 1 Commenting on the drafting process that took place within the Committee on this point, Thornberry highlights that: "[T] he consensus formula distinguishes between the general right of effective participation in public life, and the narrower issue of decisions directly affecting those indigenous groups. In the latter case, the sense of the Committee's deliberations appears to be that peoples do have a right of veto." 52 Thus, the Committee made a distinction between a right to effective participation in public life and a right to consent in decisions that directly affect indigenous peoples. This approach is reflected within the proposed text of the UN Declaration. ${ }^{53}$ Yet, the Declaration also participates in the development of an important area of international law regarding indigenous peoples' rights by referring to the principle of free and informed consent. Article 32 of the Declaration states:

1. Indigenous peoples have the right to determine and develop priorities and strategies for the development or use of their lands or territories and other resources.

2. States shall consult and cooperate in good faith with the indigenous peoples concerned through their own representative institutions in order to obtain their free and informed consent prior to the approval of any project affecting their lands or territories and other resources, particularly in connection with the development, utilization or exploitation of their mineral, water or other resources.

51) CERD, General Recommendation 23 (51), UN Doc. CERD/C/365, in A/52/18, Annex V (1997), para. 3.

52) Thornberry, supra note 5, p. 217.

53) A similar approach is developed under ILO Convention 169. See Article 6 of the UN Declaration. 
Thus, regarding land rights, the UN Declaration would impose a duty on States to obtain free and informed consent from indigenous representative institutions before undertaking any development that would affect their rights over their traditional territories. ${ }^{54}$ This particular aspect of indigenous peoples' rights reflects the specific importance of land rights for indigenous peoples.

\section{Land and Territories}

The unique relationship between indigenous peoples and their lands and territories is one of the key characteristic of indigenous claims. ${ }^{55}$ All indigenous cultures have highlighted that this relationship is very different from the Western concept of land ownership as it represents a unique spiritual, cultural, social, political and economic relationship. Accordingly, it was expected that a universal declaration on the rights of indigenous peoples would reflect the importance of land rights for indigenous peoples. While during the negotiations at the WGDD all indigenous and States' representatives usually agreed on the importance of stressing and legally affirming their special relationship to the land, there were some areas of contention. The principal debates took place on the issues of collective rights and land restitution.

\subsection{Collective Land Rights}

Regarding the importance of respecting indigenous collective territorial identity, one of the issues that attracted some controversy during the drafting of the Declaration related to the reference to the term 'ethnocide'. Article 7 of the UN Draft Declaration referred to both 'ethnocide' and 'cultural genocide'. Article 7(b) established a clear link between so called 'cultural genocide' and "any action which has the aim or effect of dispossessing" indigenous peoples of their lands. Article 7 of the UN Draft Declaration stated:

Indigenous peoples have the collective and individual right not to be subject to ethnocide and cultural genocide, including the prevention of and redress for: (. . .) Any action which has the aim or effect of dispossessing them of their lands, territories or resources; ${ }^{56}$

54) On this issue, see Expanded Working Paper Submitted by Mrs. Antoanella-Iulia Motoc and the Tebtebba Foundation Offering Guidelines to Govern the Practice of Implementation of the Principle of Free, Prior and Informed Consent of Indigenous Peoples in Relation to Development Affecting Their Lands and Natural Resources, UN Doc. E/CN.4/Sub.2/AC.4/2005/WP.1.

55) See Final Working Paper Prepared by the Special Rapporteur, Mrs. Erica-Irene Daes, Human Rights of Indigenous Peoples: Indigenous Peoples and Their Relationship to Land, UN Doc. E/CN.4/Sub.2/2000/25

(30 June 2000).

56) The Proposed American Declaration does not mention genocide. See OAS Draft Inter-American Declaration on the Rights of Indigenous Peoples, Doc. OEA/Ser/L/V/II.90, Doc.9, Rev.1 (1995). 
While the terms 'cultural genocide' or 'ethnocide' do not appear in the 1948 Convention on the Prohibition of Genocide, indigenous representatives highlighted that "land was a key component of indigenous culture and dispossession of land was paramount to ethnocide." ${ }^{57}$ Many indigenous representatives stated that the removal from their traditional territories often amounted to cultural genocide as the practice of dispossession, forced relocation or population transfer amounted to the destruction of their community. Thus, the adoption of Article 7 of the Draft Declaration would have established a clear link between land dispossession and international criminal prosecution. ${ }^{58}$

However, the terms 'cultural genocide' or 'ethnocide' do not appear in the text adopted by the Human Rights Council. Nonetheless, the text still recognises the crucial connection between indigenous peoples' survival and land rights. Article 8(2)(b) affirms that "states shall provide effective mechanisms for prevention of, and redress for (...) any action which has the aim or effect of dispossessing them of their lands, territories or resources (. . .)." Generally, the text strongly upholds that land rights are at the heart of indigenous peoples' entitlements under international law. At the outset, the preamble points out "that control by indigenous peoples over developments affecting them and their lands, territories and resources will enable them to maintain and strengthen their institutions, cultures and traditions, and to promote their development in accordance with their aspirations and needs." By and large there has been a consensus on the need to strongly affirm indigenous peoples' land rights within the Declaration, and the fact that a large part of the text is dedicated to land rights illustrates this agreement.

Where the disagreement began was on the issue of collective rights. This is not limited to the sphere of indigenous peoples' rights as usually under international human rights law there is a debate on the issue of collective rights. ${ }^{59}$ However, for indigenous peoples this aspect was extremely important as land rights are seen through the lens of the community and not through the Western individual approach to property rights. During one of the sessions of the WGDD, indigenous representatives highlighted: "[E]xercise of our collective rights is not only critical to indigenous spirituality, but also [to] maintaining the inter-generational

57) UN Doc. E/CN.4/2002/98, p. 18.

58) Note that the Draft Declaration used the term "aim or effect", a requirement which is less onerous than the "specific intent" threshold. See J. Gilbert, 'Environmental Degradation as a Threat to Life: A Question of Justice?’, 6 Trinity College Law Review (2003) pp. 81-97.

59) For references, see P. Jones, 'Human Rights, Group Rights and Peoples' Rights', 21:1 H.R.Q. (1999) pp. 80-97; M. Freeman, 'Are There Collective Human Rights?', 43 Political Studies (1995) p. 25; M. Scheinin, 'How to Resolve Conflicts Between Individual and Collective Rights?', in M. Scheinin and R. Toivanen (eds.), Rethinking Non-Discrimination and Minority Rights (2005) pp. 219-238; G. Gilbert, 'Individuals, Collectivities and Rights', in N. Ghanea and A. Xanthaki (eds.), Minorities, Peoples, and Self-Determination (2005). 
nature of all our social, cultural, economic and political rights." ${ }^{\circ 0}$ They also pointed out that "a key element of indigenous collective rights is the profound social, cultural, economic and spiritual relationship of indigenous peoples with our lands, territories, resources and environment." ${ }^{61}$ The Declaration's text recognises the collective nature of land rights. For example, Article 26 states:

1. Indigenous peoples have the right to the lands, territories and resources which they have traditionally owned, occupied or otherwise used or acquired.

2. Indigenous peoples have the right to own, use, develop and control the lands, territories and resources that they possess by reason of traditional ownership or other traditional occupation or use, as well as those which they have otherwise acquired.

The bearers of the rights clearly are indigenous peoples. Thus, despite the political debates surrounding the issue of collective rights, the UN Declaration reflects the emerging legal acknowledgment of a collective nature of property rights for indigenous peoples. The IACHR in the Awas Tingni case clearly affirmed the right to property in lands for "members of indigenous communities within the framework of commonality of possession (. . .)." ${ }^{62}$ ILO Convention 169 also recognises the collective nature of property in lands for indigenous peoples, and the jurisprudence of the HRC and CERD also emphasise the collective nature of this connection. ${ }^{63}$ Hence, on this issue, the UN Declaration conforms to other international standards that are all pointing towards the emergence of indigenous peoples' collective rights to land.

Regarding the consequences of such a recognition, the Declaration's text is not as clear as other international instruments. For example, whereas other instruments make land demarcation a clear obligation for States, the Declaration remains silent on this issue. Indigenous representatives have called for the introduction of an amendment to Article 25 of the Draft Declaration's text to include a reference to the need for the demarcation of indigenous lands. ${ }^{64}$ Such references appear in the ILO Convention 169, as Article 14(2) of the Convention reads: "Governments shall take steps as necessary to identify the lands which the peoples concerned traditionally occupy, and to guarantee effective protection of their rights of ownership and possession.” The HRC has also taken a dynamic approach and interpreted Article 27 of the ICCPR as requiring States to ensure

60) Proposals by indigenous representatives, seventh session of the WGDD, UN Doc. E/CN.4/2002/98, Annex II, p. 28.

61) Ibid.

62) The Mayagna (Sumo) Awas Tingni Community v. Nicaragua, supra note 13, para. 148.

63) CERD, General Recommendation 23, supra note 51, para. 5. For a discussion on collective land rights, see J. Gilbert, Indigenous Peoples' Land Rights Under International Law: From Victims to Actors (Transnational Publishers-Martinus Nijhof, 2006) pp. 85-115.

64) UN Doc. E/CN.4/2004/81, p. 17, para. 110. 
the demarcation of indigenous peoples' territories in order to provide an effective protection of such territories. For example, the HRC recommended that Brazil ensure the demarcation of indigenous territories. The Committee stated: "[I]n light of article 27 of the Covenant, all necessary measures should be taken to ensure that the process of demarcation of indigenous lands be speedily and justly settled." ${ }^{5}$ Similarly, in the Awas Tingni case, the IACHR found that Nicaragua had not respected its obligation to demarcate land on the basis of Article 21 of the American Convention on Human Rights. ${ }^{66}$

Although there is an emergence of a clear right to land demarcation, the text adopted by the Human Rights Council does not mention a State's obligation for land demarcation. The Declaration remains vague by affirming that "states shall give legal recognition and protection to these lands, territories and resources" but does not provide for a clear obligation to demarcate indigenous lands. However, despite these limitations, the Declaration remains very strong on land rights. And it is certain that by clearly affirming the importance of the recognition of indigenous peoples' collective right to their land, the UN Declaration will participate in the development of a stronger legal corpus of laws on collective rights. In the end, the Declaration proposes a good balance between individual and collective rights. The preamble affirms "that indigenous individuals are entitled without discrimination to all human rights recognized in international law, and that indigenous peoples possess collective rights which are indispensable for their existence, well-being and integral development as peoples." This idea that collective rights and individual rights are not necessarily antonymic is certainly one of the keystones in the development of indigenous peoples' rights. Hence, the adoption of the Declaration will mark an important step towards the affirmation of collective rights for indigenous peoples.

\subsection{Dealing with the Past: From Restitution to Redress}

Indigenous peoples' rights to their lands derive from traditional occupation and indigenous laws and customs relating to land ownership. In this regard, international law is dealing with arguments of a historical nature. The preamble of the Declaration recognises that indigenous peoples have suffered historical injustices as the result of the colonisation and dispossession of their lands. Hence, even though international human rights law is concerned with the present situation facing indigenous peoples, it is certain that in addressing indigenous peoples' land rights the 'weight of history' cannot be ignored. This was the subject of 
intense debates during the drafting of the Declaration. It is reflected in the drafting of Article 26, and Article 26(2) adopted by the Human Rights Council differs from the proposed text adopted by the Sub-Commission. Article 26 of the Sub-Commission text stated:

Indigenous peoples have the right to own, develop, control and use the lands and territories, including the total environment of the lands, air, waters, coastal seas, sea-ice, flora and fauna and other resources which they have traditionally owned or otherwise occupied or used. $^{67}$

This connection between traditional occupation of lands and present day occupation was seen as controversial by several of the States involved in the work of the WGDD. For example, Australia pointed out that it would support Article 26 only if "it applied to lands that indigenous peoples currently owned or exclusively used." ${ }^{\circ}$ Whereas the text of the Draft Declaration was affirming indigenous peoples' rights to land ownership over territories owned in the past, the text adopted by the Human Rights Council recognises such right of ownership only over territories owned by indigenous peoples at present. Article 26(2) of the UN Declaration adopted by the Human Rights Council provides that:

Indigenous peoples have the right to own, use, develop and control the lands, territories and resources that they possess by reason of traditional ownership or other traditional occupation or use, as well as those which they have otherwise acquired. ${ }^{69}$

Thus, the right of ownership concerns only lands that indigenous peoples presently occupy. The connection between traditional occupation and the present day that was present in the ex-Article 26 has been suppressed. Instead, the debate on the relationship between past dispossession and contemporary land claims was relegated to the discussion on Article 27, which relates to a right to land restitution.

The issue of restitution is crucial when addressing land rights. The question of land rights is often a question of restoring lands that were taken under a past discriminatory enterprise and linked to a continuing denial of indigenous peoples' rights. Against such a background, the Draft Declaration referred to a right of restitution for indigenous peoples. Article 27 of the Draft Declaration stated:

Indigenous peoples have the right to the restitution of the lands, territories and resources which they have traditionally owned or otherwise occupied or used, and which have been confiscated, occupied, used or damaged without their free and informed consent. Where this is not possible, they have the right to just and fair compensation. Unless otherwise freely agreed upon by the peoples concerned, compensation shall take the form of lands, territories and resources equal in quality, size and legal status.

67) Emphasis added.

68) UN Doc. E/CN.4/2003/92, p. 8, para. 32.

69) Emphasis added. 
However, at the WGDD, several States expressed concern regarding the affirmation of a right to land restitution in the Declaration's text, notably highlighting that such a right might impact on third party rights. Some States also expressed concerns on this Article, arguing that such a right to restitution was not part of international legal standards. However, as pointed out by several indigenous organisations, there are clear standards on indigenous peoples' right to land restitution coming from some of the UN human rights treaty bodies. ${ }^{70}$ For example, CERD in its General Recommendation 23 on indigenous peoples affirms the existence of such a right to restitution. ${ }^{71}$ The HRC in its Concluding Observations on Guatemala also referred to indigenous peoples' right to "the restitution of communal lands." ${ }^{\prime 2}$ Despite this background, no agreement was reached on Article 27 of the Draft Declaration. This resulted in an amended version of the Article which refers to a right to redress. The Article adopted by the Human Rights Council reads:

Indigenous peoples have the right to redress, by means that can include restitution or, when this is not possible, of a just, fair and equitable compensation, for the lands, territories and resources which they have traditionally owned or otherwise occupied or used, and which have been confiscated, taken, occupied, used or damaged without their free, prior and informed consent.

Hence, restitution of land becomes part of a larger right to redress and not the main principle. Yet, regarding the practical implementation of such a right, the Declaration reaffirms the rule that restitution should be the first principle, and only when it is not possible should other methods of compensation be contemplated. This approach reflects the position adopted by CERD in its General Comment 23, which states that: "[O]nly when this is for factual reasons not possible, the right to restitution should be substituted by the right to just, fair and prompt compensation. Such compensation should as far as possible take the form of lands and territories." ${ }^{33}$ This reflects the situation that for indigenous peoples monetary compensation disregards the fact that land ownership is not merely a source of individual economic security but the core of indigenous cultures and religions. At the WGDD, indigenous peoples' representatives have emphasised "that owing to the special nature of their relationship to their lands, financial compensation did not provide adequate redress for the loss incurred." ${ }^{4}$

70) See the joint submission submitted to the WGDD on November 2005, Indigenous Peoples' Right to Restitution, UN Doc. E/CN.4/2005/WG.15/CRP.4.

71) CERD, General Recommendation 23, supra note 51, para. 5.

72) Human Rights Committee, Concluding Observations: Guatemala, UN Doc. CCPR/CO/72/GTM (27 August 2001), para. 29.

73) Ibid., para. 5.

74) Seventh session of the WGDD, UN Doc. E/CN.4/2002/98, p. 19. 
The Article adopted by the Human Rights Council integrates this concern in the form of an 'equitable compensation' that might be awarded only when restitution is not possible. This clear principle on means of redress affirmed by the UN Declaration will certainly have some important practical importance in legal decision-making at both the international and national level as the issue of remedies for past violations remains a very volatile area of international law where clear principles, such as the one affirmed in the Declaration, are needed. From this perspective, when adopted the UN Declaration could also have some interesting consequences on the broader issue of reparation for past wrongs.

\section{Conclusion}

Regarding the role of the UN human rights machinery in the development of indigenous peoples' rights, a lot of time and effort have been spent on the development of the UN Declaration on the Rights of Indigenous Peoples. One might ask whether such a focus was beneficial, as after more than 20 years of negotiation, the result might 'only' be a declaration, i.e. a non-legally binding instrument. As developed in this article, for several reasons the fight to get to a declaration is worthy. First, it has to be borne in mind that declarations are essential texts. The whole contemporary human rights framework started around the 1948 Universal Declaration on Human Rights. From this perspective, the Declaration might well be the start rather than the end. Linked to this idea, the Declaration will act as an essential affirmation of indigenous peoples' rights, as Article 42 affirms: "[T] he rights recognised herein constitute the minimum standards for the survival, dignity and well-being of the indigenous peoples of the world." As highlighted earlier, there clearly was a need for such a declaration to ensure the development of a coherent body of international law regarding indigenous peoples. The Declaration will ensure such coherence by serving as a framework for the development of future instruments regarding indigenous peoples' rights from very diverse international bodies such as WIPO or UN Educational, Scientific and Cultural Organization (UNESCO), for example.

More generally, regarding the development of human rights law, a declaration will mark an important step towards the affirmation of collective rights. By establishing a delicate balance between individual and collective rights for indigenous peoples, the Declaration will potentially illustrate that the recognition of collective rights does not necessarily amount to the denial of the rights of individuals. The clear affirmation of collective rights is crucial for the development of a truly universal understanding of human rights values. The human rights legal framework has often been criticised for being based on the Western ideal of individual rights, and from this perspective the affirmation of collective rights for indigenous 
peoples clearly indicates that such a vision is imperfect. The road might have been a long one, but in the end indigenous peoples' inputs to the text have been maintained, and this opens the way towards a more culturally diverse approach to human rights law.

Even though indigenous peoples reflect the tremendous diversity of the world, living in some of the most remote parts of the globe, it is striking to realise how they have all agreed on the need for such an international instrument that would express their right to maintain a different cultural, social and economic way of life. For centuries indigenous peoples have been the victims of international law, especially with the rule governing territorial acquisition justifying discriminatory States' practices towards indigenous peoples. ${ }^{75}$ Hence, the Declaration could be seen as one of the first formal universal affirmations on the rights of indigenous peoples under international law. It also indicates the emergence of indigenous peoples as identifiable actors of the international system. As Thornberry highlights, "international law is conceived as a kind of club and members must accept the rules." 76 Indigenous peoples are latecomers to this 'exclusive club'. Until recently, the 'exclusive club' was only open to States, and in many ways the indigenous peoples' movement has challenged such assumptions by claiming their right to access the international stage. The emphasis from the UN on partnership and mutual respect between States and indigenous peoples offers an important new forum for discussion, and the UN Declaration would certainly become an important factor for increasing such dialogue. Overall, the adoption of the UN Declaration will indicate an important departure from a bloody past where international law played an important role in the destruction of indigenous cultures, and from this perspective the Declaration is a promising step towards a future based on partnership and mutual respect. 